\title{
Early-spring survey for Batrachochytrium dendrobatidis in wild Rana dybowskii in Heilongjiang Province, China
}

\author{
Ying Wei, Kai Xu, Dong-Ze Zhu, Xiao-Feng Chen, Xiao-Long Wang* \\ Wildlife Resource College, Northeast Forestry University, 26 Hexing Road, Xiangfang District, Harbin 15004, \\ Heilongjiang Province, PR China
}

\begin{abstract}
Batrachochytrium dendrobatidis has been investigated worldwide because of its importance in population declines in multiple species of amphibians; however, little is known regarding the disease status of all native amphibian species in China. The present study is the first survey of chytridiomycosis in free-ranging amphibian populations in China, and it examined the possible presence of $B$. dendrobatidis in Rana dybowskii in northeastern China (Heilongjiang Province). $R$. dybowskii is mainly distributed in the northeast part of China and is intensively hunted for human consumption, making populations vulnerable to extirpation in the event of additional stresses from disease epidemics. The survey was performed in early spring of 2008, using a PCR assay, histological examination of skin samples, and zoospore culture. In total, 191 frogs were examined; thus, a $95 \%$ confidence limit for prevalence of $1.57 \%$ was selected. Our results demonstrate that $R$. dybowskii is currently free from chytridiomycosis in Heilongjiang, even though the natural conditions of the sampling sites are suitable for the occurrence of $B$. dendrobatidis. Central and local governments should implement strict management measures to prevent the escape of non-native commercial amphibian species into this area, which might endanger local populations of native species.
\end{abstract}

KEY WORDS: Batrachochytrium dendrobatidis $\cdot$ Free-range $\cdot$ Rana dybowskii $\cdot$ Detection · China

\section{INTRODUCTION}

Batrachochytrium dendrobatidis, which belongs to the new genus Batrachochytrium (Phylum Chytridiomycota, Class Chytridiomycetes, Order Chytridiales; Longcore et al. 1999), has been identified as the causative agent of an emerging infectious disease in amphibians (Daszak et al. 2000) and may account for mass mortality, population declines, and extinction of various species of amphibians globally (Daszak et al. 2003). Since the first report of this disease (Berger et al. 1998), infections of B. dendrobatidis have been recorded in more than 90 amphibian species from Australia, New Zealand, Europe, Africa, and South, Central, and North America, from a broad range of habitats (Herrera et al. 2005).

Contrary to western countries, few investigations on the disease have been conducted in Asia. McLeod et al. (2008) revealed that Batrachochytrium dendrobatidis was not found in amphibians in Thailand in the last 60 yr. Rowley et al. (2007) also reported a negative result for the disease in 274 individuals of 4 native amphibian species and 137 imported amphibians in Hong Kong. The first case of B. dendrobatidis in Asia was reported in Japan among 45 exotic frogs of 18 species kept for breeding by a private owner (Une et al. 2008). At the same time, B. dendrobatidis was detected in 4 samples from Rhacophorus javanus, Rana chalconota, Leptobrachium hasseltii, and Limnonectes microdiscus in Indonesia (Kusrini et al. 2008). It is believed that $B$. dendrobatidis has not yet invaded in China (Xie et al. 2007).

The large land area of China and its highly varied terrain give rise to a wide array of climates and vegetation patterns that offer a variety of habitats (Xie et al. 
2007), which are exploited by 399 amphibian species ( $6.28 \%$ of the global species richness). However, few historical records are available on size changes of amphibian populations in most areas of China, and fungal diseases among natural populations have never been studied properly.

Rana dybowskii has long been hunted intensively for food consumption and scientific utilization. It is a typical inhabitant of forests in the mountain ranges of northeastern China, occupying a range of habitats from lowlands to areas above $1800 \mathrm{~m}$.

Heilongjiang Province covers about $454800 \mathrm{~km}^{2}$ and borders on Russia and North Korea. The anuran community comprises 9 species belonging to 5 families (Bombinatoridae, Bufonidae, Hylidae, Ranidae, Microhylidae). This region may be more susceptible to climate warming than any other area in China (Cheng et al. 2004), and chytridiomycosis may become more prevalent under conditions of global warming (Di Rosa et al. 2007). The purpose of the present work was to reveal the existence of chytridiomycosis and its prevalence in wild populations of Rana dybowskii in northeastern China.

\section{MATERIALS AND METHODS}

The study sites were the Kalunshan Forest Farm (Heihe), Shanhe Provincial Nature Reserve for Rana dybowskii (Acheng), the Shuangyi Forest Farm (Hebei Forest Bureau), and the Dumuhe Forest Farm (Dongfanghong Forest Bureau), which are situated in the Lesser Xingan Mountains, the Zhangguangcai Mountains, and the Wandashan Mountains, where $R$. dybowskii is mainly distributed in Heilongjiang (Fig. 1). In each of the 4 regions of collection, we chose 3 sampling sites located more than $3 \mathrm{~km}$ from each other on the banks of streams or ponds. At each sampling site, 15 samples were collected randomly. Site details are listed in Table 1. Another 11 frogs from Tieli submitted by the local forest farm were also examined (Fig. 1). These mountain areas are surrounded by ponds and streams of different sizes, offering ample habitat diversity. The climate is temperate and cold temperate continental monsoon climate; precipitation occurs throughout the year, though more intensely in summer and autumn. Frosts begin in mid-autumn and snow occurs in winter, and the minimum temperatures are recorded in January ( $\mathrm{Yu}$ et al. 2009).

A detailed survey of the area during the early spring (5 to 15 April 2008) was conducted and frogs were captured on banks after hibernation. Once collected, the specimens were brought to the laboratory, where their general condition was assessed. Ventral and toe skin was excised and kept for patho-histological, molecular biological examinations and spore cultures separately. After samples were fixed in $10 \%$ formalin and embedded in paraffin, $5 \mu \mathrm{m}$ thick tissue sections were cut and stained with hematoxylin and eosin according to routine protocols to detect the presence of chytrid fungus. The diagnosis of chytridiomycosis was made according to the guidelines provided by Berger et al. (1999). PCR was performed as described by Annis et al. (2004). Isolate culture followed the protocol suggested by Longcore (2000).

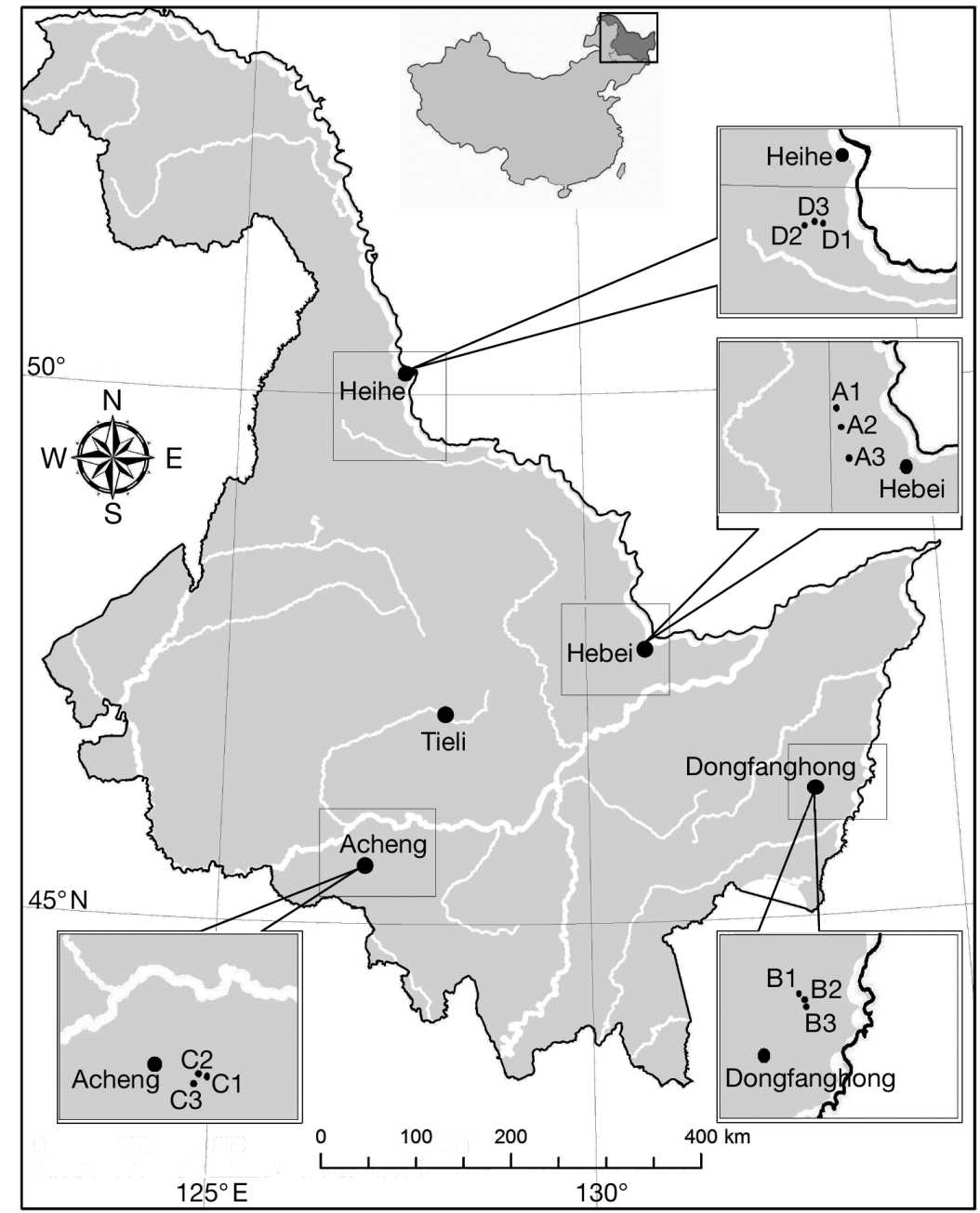

Fig. 1. Sampling regions in Heilongjiang Province, China 
Table 1. Rana dybowskii. Clinical symptoms upon gross necropsy

\begin{tabular}{|c|c|c|c|c|c|}
\hline Regions & Location & $\begin{array}{l}\text { Elevation } \\
\quad(\mathrm{m})\end{array}$ & $\begin{array}{l}\text { No. with lesions } \\
\text { /no. examined }\end{array}$ & $\begin{array}{l}\text { Collection } \\
\text { no. }\end{array}$ & Clinical signs \\
\hline Hebei & $47^{\circ} 59^{\prime} 45^{\prime \prime} \mathrm{N}, 130^{\circ} 06^{\prime} 28^{\prime \prime} \mathrm{E}$ & 273 & $1 / 15$ & A106 & Skin trauma on ventral surface and limbs \\
\hline Forest & $47^{\circ} 52^{\prime} 51^{\prime \prime} \mathrm{N}, 130^{\circ} 10^{\prime} 36^{\prime \prime} \mathrm{E}$ & 226 & $1 / 15$ & A204 & Skin ulcers on dorsal and ventral part \\
\hline \multirow[t]{2}{*}{ Bureau } & $47^{\circ} 39^{\prime} 58^{\prime \prime} \mathrm{N}, 130^{\circ} 18^{\prime} 22^{\prime \prime} \mathrm{E}$ & 169 & $2 / 15$ & A303 & Edema under skin \\
\hline & & & & A312 & Small white spots on surface of liver \\
\hline \multirow{2}{*}{$\begin{array}{l}\text { Dongfang- } \\
\text { hong }\end{array}$} & $46^{\circ} 24^{\prime} 11^{\prime \prime} \mathrm{N}, 133^{\circ} 26^{\prime} 38^{\prime \prime} \mathrm{E}$ & 186 & $2 / 15$ & B114 & Skin ulcers on fore-limbs \\
\hline & & & & B115 & Trauma on ventral skin \\
\hline Forest & $46^{\circ} 21^{\prime} 15^{\prime \prime} \mathrm{N}, 133^{\circ} 30^{\prime} 12^{\prime \prime} \mathrm{E}$ & 87 & $0 / 15$ & & \\
\hline Bureau & $46^{\circ} 21^{\prime} 15^{\prime \prime} \mathrm{N}, 133^{\circ} 30^{\prime} 12^{\prime \prime} \mathrm{E}$ & 103 & $1 / 15$ & B308 & Small white spots on surface of liver \\
\hline \multirow[t]{5}{*}{$\begin{array}{l}\text { Acheng } \\
\text { City }\end{array}$} & $45^{\circ} 28^{\prime} 49^{\prime \prime} \mathrm{N}, 127^{\circ} 35^{\prime} 36^{\prime \prime} \mathrm{E}$ & 343 & $1 / 15$ & C111 & $\begin{array}{l}\text { Hematoma under skin and congestion } \\
\text { of intestinal tract }\end{array}$ \\
\hline & $45^{\circ} 28^{\prime} 54^{\prime \prime} \mathrm{N}, 127^{\circ} 33^{\prime} 52^{\prime \prime} \mathrm{E}$ & 351 & $2 / 15$ & C208 & $\begin{array}{l}\text { Swollen spleen and gall, congestion } \\
\text { of intestinal tract }\end{array}$ \\
\hline & & & & C209 & Congestion in lung and hypodermis \\
\hline & $45^{\circ} 27^{\prime} 10^{\prime \prime} \mathrm{N}, 127^{\circ} 31^{\prime} 55^{\prime \prime} \mathrm{E}$ & 322 & $2 / 15$ & C307 & Congestion of skin \\
\hline & & & & C315 & $\begin{array}{l}\text { Edema under skin, grey color of liver } \\
\text { with blutene chloaide }\end{array}$ \\
\hline Heihe & $49^{\circ} 51^{\prime} 19^{\prime \prime} \mathrm{N}, 127^{\circ} 11^{\prime} 04^{\prime \prime} \mathrm{E}$ & 153 & $1 / 15$ & D107 & Trauma on ventral skin \\
\hline \multirow[t]{3}{*}{ City } & $49^{\circ} 51^{\prime} 28^{\prime \prime} \mathrm{N}, 127^{\circ} 02^{\prime} 15^{\prime \prime} \mathrm{E}$ & 360 & $2 / 15$ & D201 & Congestion in hypodermis \\
\hline & & & & D206 & Small skin ulcers on dorsal part \\
\hline & $49^{\circ} 52^{\prime} 07^{\prime \prime} \mathrm{N}, 127^{\circ} 04^{\prime} 07^{\prime \prime} \mathrm{E}$ & 309 & $1 / 15$ & D305 & Yellow spots on liver \\
\hline
\end{tabular}

\section{RESULTS}

Results of PCR, patho-histological examination, and zoospore culture indicated no evidence of Batrachochytrium dendrobatidis infection in wild Rana dybowskii populations in our study area. The results of the laboratory diagnosis of the specimens' general condition are shown in Table 1.

\section{DISCUSSION AND CONCLUSIONS}

Our results from 191 sampled individuals provide no evidence to support the presence of the chytrid fungus in the population of Rana dybowskii in the area under investigation.

We assumed that a $95 \%$ confidence limit for prevalence is $1.57 \%$. Considering that in other regions, Batrachochytrium dendrobatidis generally occurs at greater than $5 \%$ prevalence when endemic and weather conditions are favorable (Rowley et al. 2007), it appears that Rana dybowskii is free from B. dendrobatidis.

The early-spring environmental conditions (e.g. temperature, altitude, latitude) of the survey area are suitable for the occurrence of Batrachochytrium dendrobatidis according to previous records (Berger et al. 2004, Ouellet et al. 2005, Drew et al. 2006, Kriger et al. 2007). Temperature appears to be associated with outbreaks of fungal skin infections in amphibians. The optimal temperature for the development of the fungus is 17 to $25^{\circ} \mathrm{C}$ under laboratory conditions (Piotrowski et al.
2004); however, B. dendrobatidis can grow within a wide range of temperatures $\left(4\right.$ to $25^{\circ} \mathrm{C}$; Piotrowski et al. 2004). A previous study also illustrated that the chytrid fungus grows best at cooler temperatures (Longcore et al. 1999). At the sampling sites, the multi-year average temperature at the beginning of April is between 1 and $5^{\circ} \mathrm{C}$ with a fluctuation of $7.5^{\circ} \mathrm{C}$ (http://database.ce. cn/gqzlk/sgl/hlj/hldl/200711/14/t20071114_13597020. shtml); thus the average temperature is still within the range of temperatures that support the existence of $B$. dendrobatidis. The wide fluctuation of temperature in early spring here may disturb the immune systems of amphibians and may increase the probability of disease occurrence (Clem et al. 1991, Maniero \& Carey 1997).

The collection sites were situated between 87 and $360 \mathrm{~m}$ in elevation and between $45^{\circ} 27^{\prime} 10^{\prime \prime}$ and $49^{\circ} 52^{\prime} 07^{\prime \prime} \mathrm{N}$ in latitude. Given discoveries of Batrachochytrium dendrobatidis across broad geographical ranges (Bosch et al. 2001, Beard \& O'Neill 2005), it is reasonable to believe that elevation and latitude are not key factors preventing chytridiomycosis from being prevalent in our samples and thus the factors that prevent $B$. dendrobatidis from being prevalent need further analysis.

Taking behavioral ecology into consideration, the cooler season may have decreased the activity of amphibians in our study. The lack of available hosts for the fungus to infect during this season may have been a reason why no cases of Batrachochytrium dendrobatidis were detected, even though other environmental variables were optimal for fungal growth. As in most 
cases of wildlife epidemiological research, susceptibility to pathogens is always an important factor for detection. The unknown susceptibility of Rana dybowskii to $B$. dendrobatidis prevents us from drawing definite conclusions regarding the lack of chytridiomycosis prevalence in Heilongjiang.

This is the first investigation of chytrid fungus in wild Rana dybowskii in China. The negative result suggested that in the investigated area, $R$. dybowskii is currently free from Batrachochytrium dendrobatidis, which is noteworthy from the aspects of conservation biology and conservation medicine. The lack of positive results in this area of China adjacent to North Korea provides evidence that $B$. dendrobatidis has not yet extended north along the Korean Peninsula into China. Combining this with the fact that bullfrogs, which are carriers of $B$. dendrobatidis (Daszak et al. 2004), have been introduced into Heilongjiang Province for food consumption, it raises protection and monitoring demands for native populations and the greater wildlife community. Central and local governments should implement strict management measures to prevent the escape of non-native commercial amphibian species into this area, which might endanger local populations of native species.

Acknowledgements. We thank J. E. Longcore, School of Biology \& Ecology, University of Maine (USA), for providing positive controls for Batrachochytrium dendrobatidis detection by PCR and for identification of the cultured B. dendrobatidis.

\section{LITERATURE CITED}

Annis SL, Dastoor FP, Ziel H, Daszak P, Longcore JE (2004) A DNA-based assay identifies Batrachochytrium dendrobatidis in amphibians. J Wildl Dis 40:420-428

Beard KH, O'Neill EM (2005) Infection of an invasive frog Eleutherodactylus coqui by the chytrid fungus Batrachochytrium dendrobatidis in Hawaii. Biol Conserv 126: 591-595

> Berger L, Speare R, Daszak P, Green DE, and others (1998) Chytridiomycosis causes amphibian mortality associated with population declines in the rain forests of Australia and Central America. Proc Natl Acad Sci USA 95:9031-9036

Berger L, Speare R, Kent A (1999) Diagnosis of chytridiomycosis in amphibians by histologic examination. Available at: www.jcu.edu.au/school/phtm/PHTM/frogs/histo/ chhisto.htm

Berger L, Speare R, Hines H, Marantelli G, and others (2004) Effect of season and temperature on mortality in amphibians due to chytridiomycosis. Aust Vet J 82:31-36

Bosch J, Martnez-Solano I, García-París M (2001) Evidence of a chytrid fungus infection involved in the decline of the common midwife toad (Alytes obstetricans) in protected areas of central Spain. Biol Conserv 97:331-337

Cheng LX, Zhou XJ, Li WL, Luo YF, Zhu WQ (2004) Characteristics of the climate change and its formation mechanism in China in last 80 years. Acta Meteorol Sin 62:634-646

Editorial responsibility: Alex Hyatt,

Geelong, Victoria, Australia
Clem LS, Miller NW, Bly JE (1991) Evolution of lymphocyte subpopulations, their interactions, and temperature sensitivities. In: Warr GW, Cohen N (eds) Phylogenesis of immune functions. CRC Press, Boca Raton, FL, p 191-210

> Daszak P, Cunningham AA, Hyatt AD (2000) Emerging infectious diseases of wildlife - threats to biodiversity and human health. Science 287:443-449

Daszak P, Cunningham AA, Hyatt AD (2003) Infectious disease and amphibian population declines. Divers Distrib 9: $141-150$

Daszak P, Strieby A, Cunningham AA, Longcore JE, Brown CC, Porter D (2004) Experimental evidence that the bullfrog (Rana catesbeiana) is a potential carrier of chytridiomycosis, an emerging fungal disease of amphibians. Herpetol J 14:201-207

> Di Rosa I, Simoncelli F, Fagotti A, Pascolini R (2007) The proximate cause of frog declines? Nature 447:E4-E5

> Drew A, Allen EJ, Allen LJS (2006) Analysis of climatic and geographic factors affecting the presence of chytridiomycosis in Australia. Dis Aquat Org 68:245-250

> Herrera RA, Steciow MM, Natale GS (2005) Chytrid fungus parasitizing the wild amphibian Leptodactylus ocellatus (Anura: Leptodactylidae) in Argentina. Dis Aquat Org 64: 247-252

> Kriger KM, Pereoglou F, Hero JM (2007) Latitudinal variation in the prevalence and intensity of chytrid (Batrachochytrium dendrobatidis) infection in eastern Australia. Conserv Biol 21:1280-1290

> Kusrini MD, Skerratt LF, Garland S, Berger L, Endarwin W (2008) Chytridiomycosis in frogs of Mount Gede Pangrango, Indonesia. Dis Aquat Org 82:187-194

Longcore JE (2000) Culture technics for amphibian chytrids: recognizing, isolating, and culturing Batrachochytrium dendrobatidis from amphibians. Proceedings of the 'Getting the jump! on amphibian diseases' conference/workshop. Cairns, Aug 26-30, 2000. James Cook University, Townsville, p 52-54. www.jcu.edu.au/school/phtm/PHTM/ frogs/bdprotocols.htm

> Longcore JE, Pessier AP, Nichols DK (1999) Batrachochytrium dendrobatidis gen. et sp. nov., a chytrid pathogenic to amphibians. Mycologia 91:219-227

Maniero GD, Carey C (1997) Changes in selected aspects of immune function in the leopard forg, Rana pipiens, associated with exposure to cold. J Comp Physiol B 167:256-263

McLeod DS, Sheridan JA, Jiraungkoorskul W, Khonsue W (2008) A survey for chytrid fungus in Thai amphibians. Raffles Bull Zool 56:199-204

> Ouellet M, Midaelian I, Pauli BD, Rodrigue J, Green DM (2005) Historical evidence of widespread chytrid infection in North American amphibian populations. Conserv Biol 19:1431-1440

Piotrowski JS, Annis SL, Longcore JE (2004) Physiology of Batrachochytrium dendrobatidis, a chytrid pathogen of amphibians. Mycologia 96:9-15

> Rowley JJL, Chan SKF, Tang WS, Speare R, and others (2007) Survey for the amphibian chytrid Batrachochytrium dendrobatidis in Hong Kong in native amphibians and in the international amphibian trade. Dis Aquat Org 78:87-95

> Une Y, Kadekaru S, Tamukai K, Goka K, Kuroki T (2008) First report of spontaneous chytridiomycosis in frogs in Asia. Dis Aquat Org 82:157-160

Xie F, Lau MW, Stuart SN, Chanson JS, Cox NA, Fischman DL (2007) Conservation needs of amphibians in China: a review. Sci China C Life Sci 50:265-276

Yu CL, Li S, Liu D (2009) Effects of climate change on boundaries of ecogeographical regions in Heilongjiang Province. Sci Silvae Sin 45:8-13

Submitted: March 25, 2009; Accepted: October 30, 2009

Proofs received from author(s): February 5, 2010 